\title{
Blusukan, Komunikasi Politik Indonesia di Era Jokowi: Kajian Literatur Awal
}

\author{
Ismail Suardi Wekke \\ Institut Agama Islam Negeri (IAIN) Sorong \\ Email: iswekke@gmail.com
}

Blusukan dimaknai sebagai tatap muka (Novitasari, \& Harsanti, 2019). Walau disebut dengan melodramatic (Lestari, \& Johar, 2016). Begitu pula ketika Zuckerberg berkunjung ke Tanah Abang, Jakarta bahkan mempercakapkan blusukan itu ke Jokowi. Kedekatan dan juga entertainment elektoral menjadikan ini pilihan politisi. Dengan biaya yang relative murah, dan memberikan "kebanggaan" semu kepada masyarakat.

Terdapat tiga disertasi yang menganalisis blusukan sebagai bagian dari politik (Oktavia, 2014; Suntama, 2016; Muttaqin, 2016). Sementara satu skripsi (Kokarkin, 2018).

Topik penelitian terkait blusukan beragam. Tidak saja dalam pandangan ilmu politik tetapi bahkan sampai pada topik penentuan awal bulan qamariah (Hamdun, 2014).

Blusukan dikenal sebagai gaya atau metode komunikasi politik sejak Jokowi masih di Solo. Perlu ditelusuri, apakah ini sejak pencalonan walikota atau setelah menjadi walikota. Hanya saja, untuk kunjungan langsung ke masyarakat, Soeharto dan SBY juga melakukannya. Dilabeli dengan kata blusukan, merujuk kepada Jokowi.

Ini kemudian diadaptasi di Solok (Hawa, Naryoso, Yulianto, Gono, \& Ayun, 2016), Batu (Novitasari, \& Harsanti, 2019), Surabaya (Fachrudin, \& Yuwono, 2017).

\section{Bibliography}

Asri, A. A. S. M. A. N., \& Darma, G. S., (2020). Revealing the digital leadership spurs in 4.0 industrial revolution. International Journal of Business, Economics \& Management, 3(1), 93-100. DOI: 10.31295/ijbem.v3n1.135

Anggalia, A., \& Efriza, E. (2020). Strategi Kampanye Model Blusukan Joko Widodo Dalam Pemenangan Pemilihan Umum Kepala Daerah Kota Jakarta Tahun 2012 (Studi Kasus Di Kecamatan Kemayoran, Jakarta Pusat). Jurnal Renaissance, 5(2), 657-669.

Arif, A. (2018). Jokowi's Populism, Wealth and Local Democracy in Solo City. KnE Social Sciences, 16-25.

Darto, M. (2014). Memimpin Perubahan. Jurnal Borneo Administrator, 10(1).

Darto, M. (2014). Menghadirkan (kembali) Negara. Jurnal Borneo Administrator, 10(2).

Fachrudin, M. A., \& Yuwono, T. (2017). Inovasi Kepemimpinan Kepala Daerah (Studi Kasus: Walikota Surabaya Ir. Tri Rismaharini, MT). Journal of Politic and Government Studies, 6(2), 141-150.

Gama, B., Bani Sudardi, W. A., \& Wijaya, M. (2019). Blusukan and Personal Branding of Regional Head Election Candidates in Solo City. ACHITS 2019: Proceedings of the 1st Asian Conference on Humanities, Industry, and Technology for Society, ACHITS 2019, 30 31 July 2019, Surabaya, Indonesia (p. 238). European Alliance for Innovation.

Gama, B., Bani Sudardi, W. A., \& Wijaya, M. Blusukan dan Kampanye Pilkada Kota Solo. Komunikasi Politik di Indonesia, 135.

Gama, B., Sudardi, B., \& Wakid Abdullah, M. W. (2017). Daya Linuwih, Political Actor Candidate Of The Solo Pilkada. International Journal of Low, Government and Counication, 2(5), 100-107. 
Gama, B., Sudardi, B., Abdullah, W., \& Wijaya, M. (2018). Blusukan Cultural as a Political Power in The Regional Head Election of Surakarta. In 2nd Workshop on Language, Literature and Society for Education. European Alliance for Innovation (EAI).

Gama, B., Sudardi, B., Abdullah, W., \& Wijaya, M. (2019). Construction of Blusukan Meaning in the Campaign of Regional Heads. Social Science and Humanities Journal, 1416-1427.

Hamdun, H. (2014). Pendekatan Blusukan Jokowi-JK Sebagai Titik Temu Unifikasi Penetapan Awal Bulan Qamariah di Indonesia. Al-'Adalah, 12(2), 333-352.

Hawa, S., Naryoso, A., Yulianto, M., Gono, J. M., \& Ayun, P. Q. (2016). Political Public Relations Campaign for Election of Mayor and Deputy Mayor of Solok Period 2016-2020 Division Public Relations Coordinator. Interaksi Online, 4(2), 1-11.

Istianto, B. (2014). Bureaucratic Stagnation Versus the New Hope of the President of the Republic of Indonesia Joko Widodo. Journal of US-China Public Administration, 11(12), 960-972.

Khaerah, N., \& Kesmawan, A. P. (2015). Blasukan Sebagai New Cultural Komunikasi Politik Pada Pilkada Serentak 2015 Di Indonesia. Prosiding Seminar Nasional Pilkada Serentak.

Kokarkin, F. (2018). Makna Gambar Kisah Blusukan Jokowi Dalam Menciptakan Personal Branding Jokowi. Skripsi. Prodi Hubungan Masyarakat Fakultas Ilmu Komunikasi Universitas Padjadjaran.

Kusuma, S. (2014). Komunikasi Politik di Komunitas Virtual. Jurnal Interact, 3(1), 43-54.

Ladiqi, S., \& Salleh, M. A. (2018). Democracy and Responsiveness in Maritime Country: Interrelations Between 'blusukan' of Jokowi and the Development of Infrastructures of Ocean Toll. E\&ES, 156(1), 012048.

Lestari, L., \& Johar, S. S. (2016). Kesan Jokowi dan masyarakat melodramatik. Journal of Techno Social, 12, 1-11.

Muttaqin, Z. (2016). Konstruksi Makna Gaya Blusukan (studi Fenomenologi Tentang Konstruksi Makna Gaya Blusukan Gubenur Joko Widodo Bagi Masyarakat Jakarta Pusat). (Doctoral Dissertation, Universitas Komputer Indonesia).

Nasution, S. (2014). BLUSUKAN: Menelisik Gaya Kepemimpinan Nizam al-Muluk. MIQOT: Jurnal Ilmu-ilmu Keislaman, 38(1).

Novitasari, R., \& Harsanti, T. D. (2019). Strategi Calon Kepala Daerah Perempuan Dalam Kontestasi Politik di Kota Batu Tahun 2017. Waskita: Jurnal Pendidikan Nilai dan Pembangunan Karakter, 3(1), 23-37.

Nurabadi, A. A., Nurabadi, A., Sucipto, S., \& Gunawan, I. (2019, December). Informal Supervision Model "Managing by Walking About" in Improving Quality of Learning. In 5th International Conference on Education and Technology (ICET 2019). Atlantis Press.

Oktavia, A. (2014). Analisis Pendekatan Komunikasi Kepemimpinan Jokowi Sebagai Gubernur DKI Jakarta. (Doctoral dissertation, FISIP).

Rahmi, P. A. (2015). Kepemimpinan Kepala Daerah (Studi Kasus Walikota Surabaya, Tri Rismaharini dalam Perspektif Emotional Intelligence). Kebijakan dan Manajemen Publik 3(2), 112-121.

Septianto, N., Amista, B. R., Prabaningrum, J., Kumalla, R., Setyowati, R., \& Sutaryanto, S. (2017). Blusukan Budaya: Cultural Learning Innovations Once Life Skill Training Through Art of Dance. Proceeding International Seminar of Primary Education (Vol. 1).

Setyawan, A. A. (2019). Pastoral" Blusukan" as a Manifestation of Incarnation Theology: in the Context of Purwokerto Diocese. Logos, 14(1), 15-28.

Simorangkir, D. N., \& Pamungkas, S. (2017). Strategic political communication through storytelling: A case study of the "Democreative Tales of Jokowi's Blusukan" comics. Public Relations Journal Special Issue: Public Relations Practices in Asia.

Suntama, S. (2016). Representasi Komunikasi Politik Jokowi (Analisis Wacana Pemberitaan Blusukan Jokowi di Koran KOMPAS dan REPUBLKA). Doctoral dissertation, Universitas Mecu Buana Jakarta). 
Syamsuddin, D., Wijaya, V., \& Bernando, A. (2019, March). The phenomenon of blusukan strategy with 3D AVATAR concept in political campaign of West Java governor (A case study: Mr Ridwan Kamil and Mr Uu Ruzhanuk Ulum as candidate election). Journal of Physics: Conference Series (Vol. 1175, No. 1, p. 012241). IOP Publishing.

Tempo. (2014). Zuckerberg to Jokowi: What is Blusukan?.

Triyanto, T., Risnawati, R., \& Basuki, U. (2014). Persepsi Masyarakat Etnis Tionghoa Surabaya Terhadap Acara Pojok Kampung Segmen Blusukan Pecinan Di Jtv Surabaya. Jurnal Aspikom, 2(3), 154-164.

Usat, Y. (2019). Kepemimpinan Blusukan: Model Kepemimpinan Kristen Yang Membumi. Integritas: Jurnal Teologi, 1(2), 93-100.

Zulkarnain, A., \& Harris, S. (2017). Fenomena Blusukan Dalam Model Kepemimpinan Politik Joko Widodo. POLITIK, 13(1). 